\title{
ASSORTATIVE MATING FOR A METRICAL CHARACTERISTIC IN DROSOPHILA
}

\author{
P. A. PARSONS \\ Department of Genetics, University of Melbourne, Victoria, Australia
}

\section{INTRODUCTION}

Received 26.x.64

Assortative (non-random) mating has been studied using mutant stocks, particularly in some Drosophila species (Merrell, 1949; Rendel, 1944, 1951). Mather and Harrison (1949) showed mating preferences for two wild type stocks of flies and selected lines derived from them. Santibañez and Waddington (1958) summarised many of the earlier relevant experiments in Drosophila, and showed a tendency for positive assortative mating for a series of inbred lines in experiments they carried out.

In the wild, positive assortative mating has been found between the various colour forms of the Blue-Snow Goose (Cooch and Beardmore, 1959) and the Arctic Skua (O'Donald, 1959). Negative assortative mating may perhaps occur in the wild for various forms of the moth Panaxia dominula (Sheppard, 1952). This can be inferred from male and female choice experiments, using phenotypes found in the wild.

In man, positive assortative mating has been found for numerous characteristics, e.g. for physical characteristics such as stature and forearm length (Pearson and Lee, 1903). Fisher (1930) argued that positive assortative mating is potentially an important agent promoting evolutionary change, since its principal biometric effect is to increase the genetic variance, so increasing in this way the effect of selection on human stature by perhaps more than 20 per cent. Even so, the study of assortative mating in man has been strangely neglected until recently. Spuhler (1962) summarised some of the earlier surveys on assortative mating for physical, psychological and sociological characteristics, all of which give positive correlation coefficients between mates, although some are not significant. Data of his own for 43 physical measurements give positive correlation coefficients for $4 \mathrm{I}$ measurements of which 24 were significant at the I per cent. level and 5 at the 5 per cent. level. Some or most of these measurements are probably intercorrelated; a multi-variate analysis would be needed to ascertain the relative independence of each measurement from every other. Assuming that these physical measurements are heritable, then assortative mating must be, as Fisher (1930) argued, an agent important in modifying the genetic composition of a population. Correlations between relatives and twin studies have amply demonstrated 
the heritability of many of these physical measurements (Fisher, I9I8; Clark, 1956; Spuhler, I962).

We will not, here, discuss the non-physical characteristics, since in this paper we will be concerned with a physical characteristic in Drosophila melanogasier, namely the number of sternopleural chaetæ of mating flies. This characteristic was chosen because it is easy to score, so that a large amount of data can be readily obtained. Furthermore, when fly size is altered by environmental means, sternopleural chaeta number is directly correlated with fly size (Parsons, I 96 I), although the genes for fly size and sternopleural chaeta number are not necessarily identical. In fact, of 15 polygenes discussed by Thoday, Gibson and Spickett (1963), 13 influence sternopleural chaeta number, one influences fly size and one influences both.

\section{METHOD}

Forty virgin females and males of the Canton-S stock were aged for 3 days and then placed together in a mating chamber which consisted of a jar mounted horizontally on a stand. A Ioo-watt light source was mounted about $40 \mathrm{~cm}$. horizontally from the base of the jar so that, attracted by the light, the flies tended to congregate in the region of the base. The jar was $11 \mathrm{~cm}$. long and the diameter of the base $5 \frac{1}{2} \mathrm{~cm}$. A glass tube was fixed into the lid of the jar, such that it could be moved around inside the jar. As soon as a pair commenced mating, they were sucked out through the tube into a trap, the mating pairs being then stored separately to await scoring. Mating pairs could usually be removed without disturbing the other flies in the jar, or without breaking up the pair. Pairs were extracted until about one-half of the flies had mated, then the remaining flies were stored together to await scoring.

There were three contrasts based on larval density levels:-

I. Flies grown at a population density of 25 larvæ per vial (10 $\mathrm{cm}$. long with a base of $2 \frac{1}{2} \mathrm{~cm}$. diameter, and containing food about $2 \mathrm{~cm}$. deep).

2. Flies grown at a population density of 200 larvæ per vial.

3. A mixture of 20 males and females from (1) and (2) was used in the mating chamber, so making up 40 flies of each sex.

For simplicity, these three contrasts will be referred to as low, high and mixed levels throughout the remainder of this paper.

\section{RESULTS}

Mean sternopleural chaeta numbers with standard deviations and coefficients of variation are given in table $\mathrm{I}$. Also included is the " asymmetry" of sternopleural chaeta number, computed by taking the sum of the absolute differences in chaeta number between the left- and right-hand sides of the flies, $\mathrm{A}$, divided by the total number of chaetæ, T, over all flies of a given sex for a given contrast. This measure, $\mathrm{A} / \mathrm{T}$, has been used in various other studies for assessing levels of developmental variability (Thoday, I955; Beardmore, I96o; Parsons, I96I). It seems more correct than using just the sum A since it takes into account fly size variations. Correlation coefficients between the members of mated pairs are given in table $\mathrm{I}$. The correlation coefficients for unmated pairs represent flies of the opposite sex arbitrarily paired together as the unmated flies were counted, 
ASSORTATIVE MATING IN DROSOPHILA

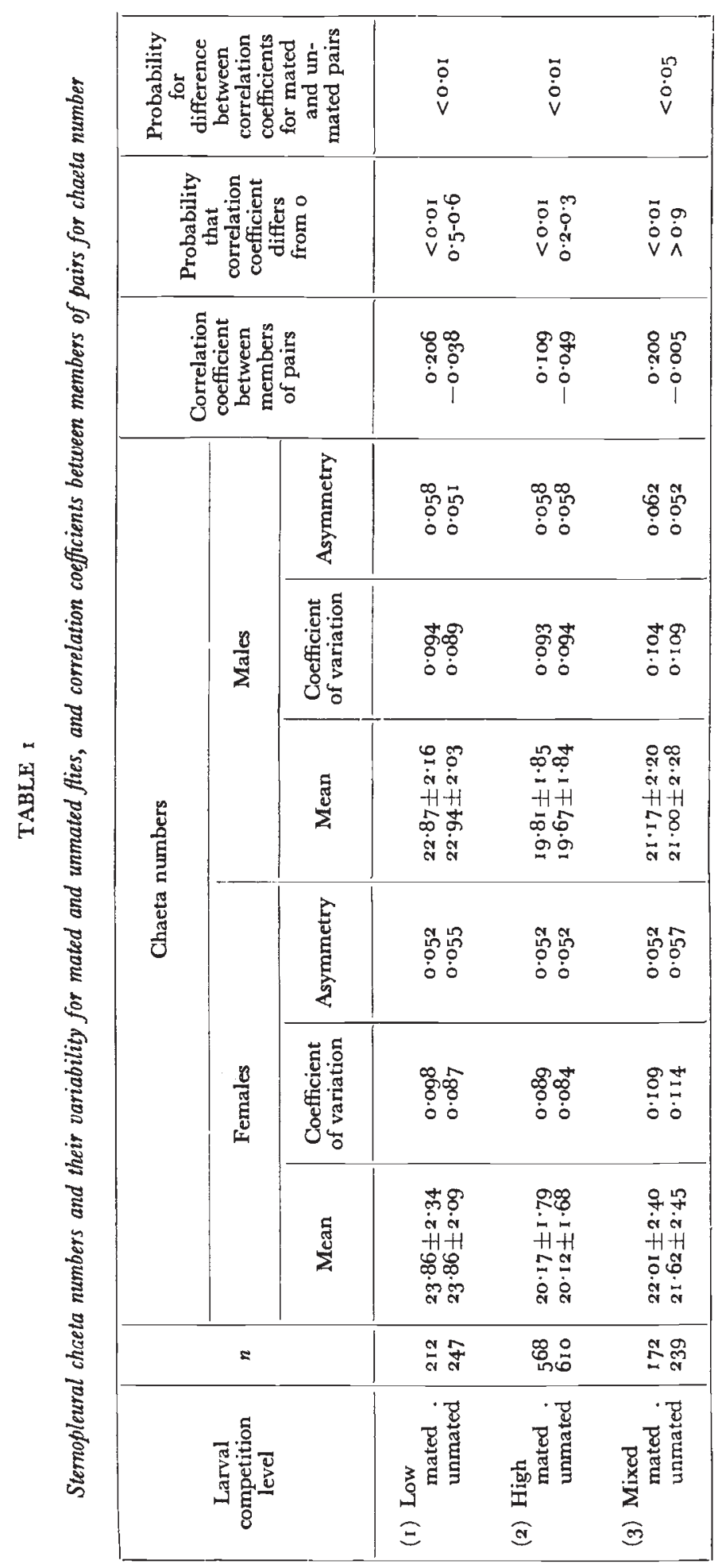


and therefore represent control values, since the pairing was approximately at random.

Mean chaeta numbers are highest at the low level and lowest at the high level. This is expected, since Parsons (I96I) has shown that at a high larval density, flies are smaller and have fewer sternopleural chaetæ than at low densities. Coefficients of variation are greater for the mixed level than for the low and high levels alone, as might be expected.

TABLE 2

Numbers of fies with scutellar chaete, which are normal and abnormal in number or position

\begin{tabular}{|c|c|c|c|c|c|c|}
\hline & \multicolumn{3}{|c|}{ Females } & \multicolumn{3}{|c|}{ Males } \\
\hline & normal & abnormal & total & normal & abnormal & total \\
\hline $\begin{array}{c}\text { Mated } \\
\text { Low } \\
\text { High } \\
\text { Mixed }\end{array}$ & $\begin{array}{r}199 \\
559 \\
160\end{array}$ & $\begin{array}{r}13 \\
9 \\
12\end{array}$ & $\begin{array}{l}212 \\
568 \\
172\end{array}$ & $\begin{array}{l}199 \\
557 \\
162\end{array}$ & $\begin{array}{l}13 \\
11 \\
10\end{array}$ & $\begin{array}{l}212 \\
568 \\
172\end{array}$ \\
\hline Totals & $9^{18}$ & 34 & $95^{2}$ & 918 & 34 & 952 \\
\hline $\begin{array}{c}\text { Lumated } \\
\text { Low } \\
\text { High } \\
\text { Mixed }\end{array}$ & $\begin{array}{l}230 \\
583 \\
220\end{array}$ & $\begin{array}{l}17 \\
27 \\
19\end{array}$ & $\begin{array}{l}247 \\
610 \\
239\end{array}$ & $\begin{array}{l}227 \\
600 \\
232\end{array}$ & $\begin{array}{r}20 \\
10 \\
7\end{array}$ & $\begin{array}{l}247 \\
610 \\
239\end{array}$ \\
\hline Totals & 1033 & 63 & 1096 & I059 & 37 & $\log 6$ \\
\hline
\end{tabular}

For the low and mixed levels, correlation coefficients close to 0.2 were obtained between members of mated pairs, which differ significantly from o $(\mathrm{P}<\mathrm{O} \cdot \mathrm{OI})$. At the high level, the correlation coefficient obtained was significantly different from o $(\mathrm{P}<\mathrm{O} \cdot \mathrm{OI})$ but close to $\mathrm{O} \cdot \mathrm{I}$. Many more matings were necessary at this level than at the other levels to achieve significance. The correlation coefficients for the unmated pairs were close to o, the differences between the correlation coefficients for the mated and unmated pairs being significant.

The coefficients of variation and asymmetry values were computed partly to look for evidence for stabilising selection, as it could be postulated that the least variable flies tend most readily to mate. There are, however, no detectable differences between the mated and unmated categories for coefficients of variation and asymmetry. It might well be that if observations were continued until a high proportion of flies had mated, then the few remaining unmated flies would be more variable than the mated flies.

Scutellar chaetæ were scored during the experiment, to look for evidence for stabilising selection. The scutellum normally has four chaetæ near its edge, namely two anterior and two posterior. Extra 
chaetæ usually occur anterior to the anterior chaetæ, or between the anterior and posterior chaetæ (interstitial chaetæ), or between the posteriors. Similarly, at any one of the normal sites, chaetæ may be missing. Occasionally, flies are found with four scutellar chaetæ, some of which are abnormal in position. In table 2, the results of classifying the flies in table I into normal and abnormal so far as scutellar chaetæ are concerned, are given, and in table $3, \chi_{1}^{2}$ values are given for the $2 \times 2$ tables made up of the two contrasts, mated and unmated, and normal and abnormal. There is clearly an excess of unmated compared with mated abnormal females at the high level of larval competition, which is reflected by a significant $\chi^{2}$ in table 3. All other contrasts

TABLE $_{3}$

$\chi_{1}^{2}$ values for $2 \times 2$ tables made up of the two contrasts, mated and unmated, and normal and abnormal (from data in table 2)

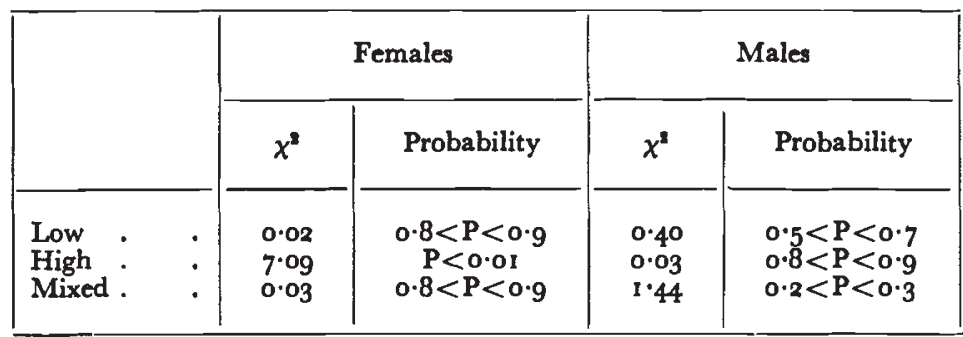

are non-significant. Thus, at least for this one contrast, flies with the normal complement of scutellar chaetæ are more successful in mating. It is difficult to know why the other contrasts do not show similar trends. Further data on this point are clearly desirable.

\section{DISCUSSION}

It is remarkable that the degree of assortative mating for sternopleural chaeta number is so similar to that found in man for many physical traits. In man, the selection of mates based on physical features is the likely reason. In Drosophila, assortative mating for chaeta number may be a direct effect of fly size such that flies of similar size find it easier to mate than flies of dissimilar sizes. There may also be behavioural differences between flies of different sizes leading to minor modifications in courtship.

Thoday and Gibson ( 1962 ) found that disruptive selection based on sternopleural chaeta number may lead to isolation, i.e. the splitting of a population into discrete sub-populations. This was accompanied by strong positive assortative mating within the sub-populations (Thoday, I964). It is thus of considerable significance that positive assortative mating exists in unselected populations as described in this paper, so that isolation by disruptive selection accompanied by assortative mating may be usual (see also Maynard Smith, I962; 
Parsons, 1962). It may be well that the evolution of positive assortative mating during divergence is a very general phenomenon.

Using artificial mixed populations of $D$. pseudoobscura and $D$. persimilis, Koopman (I 950) showed a very rapid increase in the amount of reproductive isolation between the two species as a result of natural selection over a few generations. Knight, Robertson and Waddington (1956) selected successfully for sexual isolation between flies carrying the mutants $v g$ (vestigial) and $e$ (ebony), which initially showed only weak positive assortative mating. These experiments provide further evidence for the alteration of mating preferences by selection.

The possibility of positive assortative mating developing along a cline has been discussed by O'Donald (1960) and Parsons (1962). A cline is in any case a form of disruptive selection, and may occur when different conditions of survival and reproduction occur at the opposite ends of the geographical range of a species. As pointed out by Fisher (1930) there may be a gradation of fitnesses from one end of the range to the other, such that for a locus with two alternative alleles $A$ and $a, A$ will be advantageous at one extreme and $a$ at the other. There is suggestive evidence of positive assortative mating in a colour phase cline in the Arctic Skua (O'Donald, 1959). A more complete discussion of the likely effects of assortative mating in natural populations is given by O'Donald (ig6o) and Parsons (I962).

\section{SUMMARY}

I. Positive assortative mating for a metrical characteristic, sternopleural chaeta number, has been found in Drosophila melanogaster, by scoring mating pairs extracted from a mating chamber.

2. It is considered that the evolution of positive assortative mating during isolation may be a very general phenomenon.

3. Evidence for stabilising selection was sought by comparing those that mated with those remaining unmated, with suggestive results only for scutellar chaeta variability in females.

Acknowledgments. - The help of Miss Helen Gidley in the carrying out of these experiments is gratefully acknowledged.

\section{REFERENCES}

BEARDMORE, J. A. 1960. Developmental stability in constant and fluctuating temperatures. Heredity, I4, $4 \mathrm{I}$ I -422 .

GLARK, P. J. 1956. The heritability of certain anthropometric characters ascertained from measurements of twins. American Journal of Human Genetics, 8, 49-54.

$\mathrm{COOCH}$, F. G., AND BEARDMORE, J. A. 1959. Assortative mating and reciprocal differences in the Blue-Snow Goose complex. Nature, I83, I833-1834.

FISHER, R. A. 19i8. The correlation between relatives on the supposition of Mendelian inheritance. Trans. Roy. Soc. Edin., 52, 399-433.

FISHER, R. A. 1930. The Genetical Theory of Natural Selection. Clarendon Press. Oxford.

Koopman, K. F. 1950. Natural selection for reproductive isolation between Drosophila pseudoobscura and Drosophila persimilis. Evolution, 4, 135-148. 
KNIGHT, G. R., ROBERTSON, A., AND WADDINGTON, G. H. I956. Selection for sexual isolation within a species. Evolution, $10,14-22$.

mather, K., AND harrison, B. J. 1949. The manifold effect of selection. Heredity, $3,131-162$.

MAYNARD SMITH, J. 1962. Disruptive selection, polymorphism and sympatric speciation. Nature, 195, 6o-62.

MERRELL, D. J. 1949. Selective mating in Drosophila melanogaster. Genetics, 34, 370-389.

o'donald, P. 1959. Possibility of assortive mating in the Arctic Skua. Nature, $183,1210-1211$.

o'donald, P. 1960. Assortive mating in a population in which two alleles are segregating. Heredity, ${ }_{5}, 389-396$.

PARsons, P. A. r $96 \mathrm{r}$. Fly size, emergence time and sternopleural chaeta number in Drosophila. Heredity, I6, 455-473.

PARSONS, P. A. 1962. The initial increase of a new gene under positive assortative mating. Heredity, $17,267-276$.

PEARSON, K., AND LEE, A. I903. On the laws of inheritance in man. I. Inheritance of physical characters. Biometrika, 2, 357-462.

RENDEL, J. M. 1944. Genetics and cytology of Drosophila subobscura. II. Normal and selective matings in Drosophila subobscura. 7. Genet., 46, 287-302.

RENDEL, J. M. I95I. Mating of ebony vestigial and wild type Drosophila melanogaster in light and dark. Evolution, 5, 226-230.

SANTrBAÑEZ, s. K., AND WADDINGTON, C. H. 1958. The origin of sexual isolation between different lines within a species. Evolution, 12, 485-493.

SHEPPARD, P. M. 1952. A note on non-random mating in the moth Panaxia dominula (L). Heredity, 6, 239-241.

SPUHLER, J. N. 1962. Empirical studies on quantitative human genetics. U.N./ W.H.O. Seminar on "The use of vital and health statistics for genetic and radiation studies", $24 \mathrm{I}-252$.

THodAy, J. M. 1955. Balance, heterozygosity and developmental stability. Cold. Spr. Harbor Symp. Quant. Biol., 20, 318-326.

THODAY, J. M. (1964). Genetics and the integration of reproductive systems. In Insect Reproduction. Ed. K. G. Highnam, Symp. No. 2, Royal Ent. Soc., ro8-r 19.

THODAY, J. M., AND GrBson, J. B. 1962. Isolation by disruptive selection. Nature, 193, I 164-1 166.

THODAY, J. M., Gibson, J. B., AND SPICketT, s. G. 1963. Some polygenes. Heredity, I8, 553-554. 